Vol. 1, No. 1; Jan - Mar (2021)
Quing: International Journal of Commerce and
Management
Available at https://quingpublications.com/journals/ijcm

\title{
Impact on Complications and Predictions of Self-financing School Teachers in Sivagangai District
}

\section{Thiyakesh $\mathbf{P}^{\star}$}

Ph.D., Research Scholar, Bharathiar University, Coimbatore, TN, IND.

\section{Dr. Sheeba Julius}

Assistant Professor, Department of Cooperation, T.B.M.L. College, Porayar, TN, IND.

\begin{tabular}{|c|c|}
\hline ARTICLE INFO & ABSTRACT \\
\hline Received: $02-12-2020$ & \multirow{9}{*}{$\begin{array}{l}\text { The assessment expected to choose the complications and predictions of } \\
\text { teachers working in the self-financing school in Sivagangai district, Tamil } \\
\text { Nadu. The assessment used the quantitative system for research utilizing the } \\
\text { study research plan. The respondents of the assessment were the (300) } \\
\text { educational cost-based school instructors, who are training in forty (40) } \\
\text { enlistment schools and twenty ( } 20 \text { ) CBSC schools in the Sivagangai region. } \\
\text { The assessment found that the issue looked by the teachers of private } \\
\text { schools in the district of Sivagangai; the issues on workload with a mean } \\
\text { score of } 83.39 \text { was situated to the first, long working hours with a mean } \\
\text { score of } 80.72 \text { contributed to the second position, and student's problem } \\
\text { with a mean score of } 50.22 \text { contributed the last spot. }\end{array}$} \\
\hline Received in revised form: & \\
\hline $05-03-2021$ & \\
\hline Accepted: $11-03-2021$ & \\
\hline Available online: & \\
\hline $30-03-2021$ & \\
\hline Keywords: & \\
\hline Workload; & \\
\hline $\begin{array}{l}\text { Teacher's Salary; } \\
\text { Teaching Skills. }\end{array}$ & \\
\hline
\end{tabular}

(C) 2021 Quing: IJCM, Published by Quing Publications. This is an open access article under the CC-BY 4.0 license, which allows use, distribution and reproduction in any medium, provided the original work is properly cited.

DOI: https://doi.org/10.54368/qijcm.1.1.0010

\subsection{INTRODUCTION}

Preparing is seen as essential for any nation to make and thrive socially, intellectually, and monetarily. Teachers can contribute remarkably to this prospering by keeping up the assessment of the preparation communication, so it is principal for informative experts at all levels to improve the quality and feasibility of instructors' introduction (Ball, et al., 2008; Ball and Forzani, 2009). To do educational methodologies viably and to achieve targets, schools need enlivened and submitted educators who are secure in their work and who can play out their commitments to a raised assumption (Chen, 2010).

\subsection{Statement of the Problem}

Instructing is a calling wherein predominant pieces of women are used, and it is a mentioning position. The ampleness of the informative system generally depends upon dynamic, imaginative and skilled instructors. The teachers do this piece of trim the presence of children feasibly, but then they

\footnotetext{
^Corresponding author's e-mail: thiyakesheducation@gmail.com (Thiyakesh P)
} 
face a number of issues. Elements, for instance, work shortcoming, expanded periods, steady change and ludicrous cutoff times can make issues and the prosperity of teachers could be truly affected by pressure. Moreover, beside educators themselves, work issues suffered by them can in like manner inimically impact their understudies and the learning environment. Focusing on the issue of work issues of teachers was essential and it was huge for the organization and educators to coordinate to improve the work environment and conditions to fight pressure.

\subsection{Review of Literature}

According to Muralidharan and Sundararaman (2011), teacher compensation dependent on student achievement is highly successful at optimising student learning. Nearly 75 percent of teachers in reward schools indicated that the programme improved their motivation; over 95 percent had a favourable opinion of the programme; over 85 percent had a favourable opinion of the concept of offering compensation incentives to teachers dependent on performance; and more than two-thirds of teachers thought that the government should suggest introducing the programme. In their research, (Khanale and Vaingankar, 2006) discovered that coworkers' attitudes and working environments affect teachers' job satisfaction. However, (Bhandari and Patil, 2009) discovered that job satisfaction of female teachers is affected by the working atmosphere, job existence, and pay. Singh (2009) discovered in his research that teachers employed in aided colleges are happier than teachers working in self-financing colleges.

\subsection{Objectives}

- To find various factors affecting the self-financing school teacher in Sivagangai district.

- To find the satisfaction level of self-financing school teacher Sivagangai district.

- To examination issues glanced by educators in Sivagangai district.

\subsection{METHODOLOGY}

The assessment is primarily established on fundamental and helper data. The fundamental data is accumulated from school working teachers in Sivagangai zone. Direct gathering technique was used. Fundamental data is used to get some answers concerning the scaled down level. The assistant data will be accumulated from various journals, books and magazines. Isolated subjective testing techniques will be used to pick test for data arrangement. The hard and fast model size was fixed at 300 in unpredictable and the area as the universe-comparable chance is given for taluks. There are different kinds of real gadgets for separating the accumulated data the huge gadgets used in the current examination are, for instance, mean, standard deviation and t-test.

\subsection{DATA ANALYSIS}

\subsection{Factors Influencing the Teachers to Join in Self-financing School}

The different factors which influence the teachers of self-financing school were examined like Qualification, Teaching Skills, Interested in Teaching, Status, Good Salary, Job in Nearest Place, Unemployment, Poverty, Interested in Earnings, To run Family and No other work. The respondents were drawn closer to rate different components influencing the educational cost put together school teacher with respect to a five-point scale as basic, indispensable, huge, least huge and not at all critical. It is presented in the Table 1. 
Table 1 - Factors Influencing the Teachers to Join in Self-financing School

\begin{tabular}{|l|c|c|c|}
\hline \multicolumn{1}{|c|}{ Factors } & Mean Score & SD & Z-Value \\
\hline Qualification & 7.98 & 0.71 & $12.29^{*}$ \\
\hline Teaching Skills & 7.84 & 0.93 & $8.99^{*}$ \\
\hline Interested in Teaching & 6.80 & 0.88 & $9.14^{*}$ \\
\hline Status & 6.73 & 0.82 & $6.56^{*}$ \\
\hline Good Salary & 6.56 & 1.20 & $6.33^{*}$ \\
\hline Job in Nearest Place & 5.44 & 0.98 & $4.95^{*}$ \\
\hline Unemployment & 5.32 & 0.94 & $4.59^{*}$ \\
\hline Poverty & 4.36 & 1.31 & 2.18 \\
\hline Interested in Earnings & 4.12 & 1.15 & $(-) 0.75$ \\
\hline To Run Family & 3.90 & 1.44 & $(-) 2.71$ \\
\hline No Other Work & 2.38 & 0.96 & $(-) 10.75^{*}$ \\
\hline
\end{tabular}

Source: Computed data

Note: Significant at 5\% level of significance (z-regard from table $=1.96$ )

The Table 1 shows that the critical components influencing to join the teachers of selffinancing school were ability (7.98), showing Skills (7.84), Interested in Teaching (6.80), Status (6.73) and extraordinary Salary (6.56). Z-test results show that in case of teachers of self-financing school, the saw mean motivator for factors like capacity, showing capacities, enthusiastic about acquiring, status, incredible pay, work in nearest spot, joblessness and no other work was by and large novel corresponding to the acknowledged mean assessment of 3 at 5 percent level of significance.

\subsection{Factors Influence the Job Satisfaction of the Self-financing School Teachers}

Table 2 - Factors Influence the Job Satisfaction of the Self-financing School Teachers

\begin{tabular}{|l|c|c|c|c|c|c|c|}
\hline \multicolumn{1}{|c|}{ Factors } & $\mathbf{1}$ & $\mathbf{2}$ & $\mathbf{3}$ & $\mathbf{4}$ & $\mathbf{5}$ & Mean & S.D. \\
\hline Salary & $\begin{array}{c}12 \\
(4.0)\end{array}$ & $\begin{array}{c}38 \\
(12.7)\end{array}$ & $\begin{array}{c}81 \\
(27.0)\end{array}$ & $\begin{array}{c}121 \\
(40.3)\end{array}$ & $\begin{array}{c}48 \\
(16.0)\end{array}$ & 4.89 & 1.014 \\
\hline Increments & $\begin{array}{c}15 \\
(5.0)\end{array}$ & $\begin{array}{c}32 \\
(10.7)\end{array}$ & $\begin{array}{c}87 \\
(29.0)\end{array}$ & $\begin{array}{c}117 \\
(39.0)\end{array}$ & $\begin{array}{c}49 \\
(16.3)\end{array}$ & 4.86 & 0.938 \\
\hline Student Co-operation & $\begin{array}{c}13 \\
(4.3)\end{array}$ & $\begin{array}{c}42 \\
(14.0)\end{array}$ & $\begin{array}{c}95 \\
(31.7)\end{array}$ & $\begin{array}{c}95 \\
(31.7)\end{array}$ & $\begin{array}{c}55 \\
(18.3)\end{array}$ & 4.74 & 1.053 \\
\hline Co-Teachers & $\begin{array}{c}12 \\
(4.0)\end{array}$ & $\begin{array}{c}42 \\
(12.8)\end{array}$ & $\begin{array}{c}93 \\
(33.2)\end{array}$ & $\begin{array}{c}104 \\
(37.6)\end{array}$ & $\begin{array}{c}49 \\
(15.6)\end{array}$ & 4.72 & 0.999 \\
\hline Management & $\begin{array}{c}16 \\
(2.4)\end{array}$ & $\begin{array}{c}56 \\
(14.0)\end{array}$ & $\begin{array}{c}77 \\
(31.0)\end{array}$ & $\begin{array}{c}93 \\
(34.7)\end{array}$ & $\begin{array}{c}58 \\
(16.3)\end{array}$ & 4.66 & 1.182 \\
\hline Infrastructure & $\begin{array}{c}15 \\
(5.0)\end{array}$ & $\begin{array}{c}43 \\
(14.3)\end{array}$ & $\begin{array}{c}94 \\
(31.3)\end{array}$ & $\begin{array}{c}108 \\
(36.0)\end{array}$ & $\begin{array}{c}40 \\
(13.3)\end{array}$ & 4.63 & 1.033 \\
\hline Teaching & $\begin{array}{c}14 \\
(4.7)\end{array}$ & $\begin{array}{c}44 \\
(14.7)\end{array}$ & $\begin{array}{c}101 \\
(33.7)\end{array}$ & $\begin{array}{c}97 \\
(32.3)\end{array}$ & $\begin{array}{c}44 \\
(14.7)\end{array}$ & 4.62 & 1.040 \\
\hline
\end{tabular}

Source: Computed data

Note: The characteristics decided in the areas address rates.

Table 2 shows that work satisfaction towards the self-financing school teachers. Respondents are content with pay (mean score 4.89) and increments with mean score 4.86. Moderate mean 
characteristics are recorded for understudy co-action (mean score 4.74 and co-educates with men score 4.72. Low mean characteristics are seen for the heads (mean score 4.66), system with mean score 4.63 and teaching with mean score 4.62. The overall mean for execution is 4.62.

\subsection{Problems Faced by the Teachers in Self-financing School}

In Table 3, the issues so recognized and situated by the respondents were changed over into scores by using the Garrett's Ranking Technique. The mean scores were shown up for each issue and organized in a dropping solicitation.

Table 3 - Problems Faced by the Teachers in Self-financing School

\begin{tabular}{|l|c|c|}
\hline \multicolumn{1}{|c|}{ Problems } & Mean Score & Rank \\
\hline Unsatisfied Salary & 67.55 & IV \\
\hline Workload & 83.39 & I \\
\hline Long Hours of Working & 80.72 & II \\
\hline Problem with Parents & 62.78 & V \\
\hline Problem with Student & 50.22 & VIII \\
\hline No Lesser Time & 55.63 & VI \\
\hline Co-Teachers & 72.49 & III \\
\hline Management & 52.03 & VII \\
\hline
\end{tabular}

Source: Computed data

Table 3 shows the issue looked by the educational cost based school teachers in Sivagangai district; the issue of workload with a mean score of 83.39 was situated to the first, long working hours with a mean score of 80.72 contributed to the second position, the mean score of conflict with coteachers is 72.49 contributed third position, unsatisfied salary with mean score of 67.55 contributed fourth position, parents' problem with mean score of 62.78 contributed fifth position, no lesser time with mean score 55.63 contributed sixth position, the mean score of problem with management is 52.03 contributed seventh position and student's problem with a mean score of 50.22 contributed the last spot.

\subsection{FINDINGS}

- The study imparts that the huge factors affecting to join the teachers of private school were capacity (7.98), showing Skills (7.84), Interested in Teaching (6.80), Status (6.73) and extraordinary Salary (6.56). Z-test results show that if there ought to emerge an event of nonstate funded school instructors, the saw mean motivator for factors like capacity, showing capacities, excited about obtaining, status, extraordinary pay, work in nearest spot, joblessness and no other work was essentially not exactly equivalent to the acknowledged mean assessment of 3 at 5 percent level of significance.

- The study shows that work satisfaction towards the teachers of private school. Respondents are content with pay (mean score 4.89) and increments with mean score 4.86. Moderate mean characteristics are recorded for understudy co-action (mean score 4.74 and co-teaches with men score 4.72. Low mean characteristics are seen for the heads (mean score 4.66), system with mean score 4.63 and teaching with mean score 4.62 . The overall mean for execution is 4.62 . 
- The study reveals that the issue looked by the teachers of private school in Sivagangai region; the issue of workload with a mean score of 83.39 was situated to the first, long working hours with a mean score of 80.72 contributed to the second position, and student's problem with a mean score of 50.22 contributed the last spot.

\subsection{SUGGESTIONS}

The huge thoughts are

- The establishments concentrate and give more importance to improve pay.

- The foundations steps and to diminish obligation, lessen external school review and school hostility.

- Teachers should get the moral material affirmation appropriate to their commitments.

- The board changes the viewpoints and diminishes more restrictions.

- The boss can execute some powerful ventures to adjust up the educators from stress and besides pay as demonstrated by their show. It will awaken the educators to oversee work effectively.

- Teachers should get in-organization getting ready and capable progression inside the calling to remain in contact with new teaching methods.

- The mechanical structure in the assets of preparing should be improved.

\subsection{CONCLUSION}

The assessment reasons that organization and boss assistance towards educators in redesigning position satisfaction is fundamental. All undertakings should be needed to improve the work satisfaction of instructors. Having inferred from this examination that pay and expansion is the most pursued quality of occupation satisfaction, the board should make self-prodded bunches at school. A couple of thoughts towards achieving position satisfaction and overcome the issues are selfdevelopmental opportunities, flitting courses, classes, workshops, high appreciation and grants for commendable work are a segment of the way work satisfaction can be improved. The principle contemplations making issue in training and learning Limits were materials, procedures, level of understudies and the heads. Recently referenced strategies can be setting focused, social and important in basically the sum of the schools of our country and henceforth even in Sivagangai district.

\section{REFERENCES}

Ball, D. L., \& Forzani, F. M., (2009, Nov), "The Work of Teaching and the Challenge for Teacher Education", Journal of Teacher Education, 60(5), pp. 497-511. https://doi.org/10.1177\%2F0022487109348479.

Ball, D. L., Thames, M. H., \& Phelps, G., (2008, Nov), “Content Knowledge for Teaching: What Makes it Special?" Journal of Teacher Education, 59(5), pp. 389-407. https://doi.org/10.1177\%2F0022487108324554.

Bhandari, R. K., \& Patil, N. H., (2009, Jul) “Job Satisfaction of Women Teachers”, Edu Tracks, 8(11), pp. 42-44. 
Chen, J., (2010, Apr) "Chinese Middle School Teacher Job Satisfaction and its Relationship with Teacher Moving", Asia Pacific Education Review, 11(3), pp. 263-272. https://doi.org/10.1007/s12564-010-9085-1.

Khanale, P., \& Vaingankar, A., (2006, Jul) "Analyzing 'Job Satisfaction' of a Teacher in an Institution”, The Turkish Online Journal of Educational Technology, 5(3), pp. 3-5. Available at https://eric.ed.gov/?id=EJ1102465.

Muralidharan, K., \& Sundararaman, V., (2011, Feb) "Teacher Performance Pay: Experimental Evidence from India", Journal of Political Economy, 119(1), pp. 39-77. https://doi.org/10.1086/659655.

Singh, R. K., (2009) "A Comparative Study of Teaching Effectiveness, Teaching Aptitude and Job Satisfaction of Self-financed and Government Aided Colleges". Ph.D. Thesis in Education, Agra University, UP. 